\title{
Trudności w leczeniu chorego na ostrą białaczkę szpikową z mutacją FLT3-ITD i wysokim stosunkiem allelicznym - oporność na standardową chemioterapię indukującą w połączeniu z midostauryną
}

\author{
Difficulties in the management of a patient with acute myeloid \\ leukaemia and high mutant allelic ratio FLT3-ITD - refractoriness \\ to the standard induction therapy along with midostaurin
}

\author{
Elżbieta Patkowska ${ }^{1}$, Joanna Sawczuk-Chabin ${ }^{1}$, Iwona Solarska ${ }^{2}$, \\ Katarzyna Borg ${ }^{3}$, Ewa Lech-Marańda ${ }^{1}$ \\ ${ }^{1}$ Klinika Hematologii, Instytut Hematologii i Transfuzjologii \\ ${ }^{2}$ Pracownia Biologii Molekularnej, Zakład Diagnostyki Hematologicznej, Instytut Hematologii i Transfuzjologii \\ ${ }^{3}$ Pracownia Cytogenetyki, Zakład Diagnostyki Hematologicznej, Instytut Hematologii i Transfuzjologii
}

\begin{abstract}
Streszczenie
Rozwój terapii celowanych u chorych na AML, umożliwiajacych indywidualizacje leczenia, $w$ tym zastosowanie nowych inhibitorów kinaz tyrozynowych FLT3, jest obiecujaca perspektywa dla poprawy wyników leczenia i wydtużenia czasu przeżycia chorych. Jednakże problemem pozostaje leczenie chorych z obecnościq wysokiego stosunku allelicznego FLT3 - FLT3-ITD ${ }^{\text {high }}$ - zwiqzanego $z$ wyjatkowo niekorzystnym rokowaniem. W pracy przedstawiono przypadek 20-letniego chorego na AML $z$ obecnościq FLT3-ITD high $z$ lokalizacjami pozaszpikowymi AML przy rozpoznaniu. Leczenie chorego zindywidualizowano, stosujac chemioterapie indukujaca skojarzona $z$ midostauryna. Po zastosowaniu leczenia indukujacego wedtug schematu $D A, 3+7$ ” nie osiagnieto u chorego catkowitej remisji (CR). Po wtaczeniu drugiej chemioterapii indukujacej uzyskano CR z obecnościq choroby resztkowej. Nastepnie podano jeden cykl chemioterapii konsolidujacej oraz, po zastosowaniu kondycjonowania mieloablacyjnego, przeprowadzono przeszczepienie allogenicznych krwiotwórczych komórek macierzystych od dawcy niespokrewnionego. Pacjent pozostaje $w$ CR bez obecności choroby resztkowej od 18 miesiecy.
\end{abstract}

Słowa kluczowe: ostra białaczka szpikowa, mutacja FLT3-ITD, midostauryna, wysoki stosunek alleliczny $F L T 3$

Hematologia 2020; 11, 4: 253-258

\begin{abstract}
The development of targeted therapies in AML patients enabling treatment individualization, such as new FLT3 tyrosine kinase inhibitors, is a promising option for improving treatment outcomes and prolonging patient survival. However, the treatment of patients with a high FLT3-ITD allelic ratio (FLT3-ITD ${ }^{\text {high }}$ ) associated with an extremely unfavourable prognosis remains a major clinical problem. The study presents a case of a 20-year-old patient with FLT3-ITD ${ }^{\text {high }}$ extramedullary
\end{abstract}

Adres do korespondencji: Elżbieta Patkowska, Klinika Hematologii, Instytut Hematologii i Transfuzjologii, ul. Indiry Gandhi 14, 02-776 Warszawa, tel. 223496 322, faks 223496 213, e-mail: epatkowska@ihit.waw.pl 


\begin{abstract}
$A M L$ at diagnosis. Individualized chemotherapy according to the $D A$ ' $3+7$ ' regimen combined with midostaurin was administered. After the induction treatment, complete remission (CR) was not achieved. After second induction chemotherapy, CR1 was achieved with the presence of residual disease. One cycle of consolidation chemotherapy was then administered, and after myeloablative conditioning allogeneic hematopoietic stem cell transplantation from an unrelated donor was performed. The patient has remained in CR with no residual disease for 18 months.
\end{abstract}

\title{
Key words: acute myeloid leukaemia, FLT3-ITD mutation, midostaurin, high FLT3 allelic ratio
}

Hematologia 2020; 11, 4: 253-258

\section{Wstęp}

Zastosowanie inhibitorów FLT3 w leczeniu chorych na ostrą białaczkę szpikową (AML, acute myeloid leukemia) z obecnością mutacji FLT3 jest nowym standardem leczenia chorych na AML. Midostauryna w skojarzeniu $z$ chemioterapią została zarejestrowana zarówno przez Agencję do spraw Żywności i Leków (FDA, Food and Drug Administration), jak i Europejską Agencję Leków (EMA, European Medicine Agency) do leczenia chorych na AML $z$ obecnością mutacji FLT3 w pierwszej linii leczenia AML w 2017 roku.

Kinaza FLT3 [fms-like tyrosine kinase 3; fetal liver tyrosine kinase 3 ; stem cell tyrosine kinase 1 (STK1)] należy do III klasy receptorowych kinaz tyrozynowych, podobnie jak c-KIT, PDGFR- $\alpha$, $P D G F R-\beta, C S F-1 R$. Gen kodujący FLT3 znajduje się na chromosomie 13. i składa się z 24 egzonów. Receptor FLT3 występuje w komórkach macierzystych szpiku. Składa się $z$ domeny zewnątrzkomórkowej (wiążącej ligand), przezbłonowej i dwóch domen wewnątrzkomórkowych, o aktywności kinazowej. W warunkach fizjologicznych połączenie receptora FLT3 z jego ligandem wzbudza sygnały wewnątrzkomórkowe regulujące proliferację i różnicowanie komórek. Ekspresja genu FLT3 zanika w miarę różnicowania komórek. W komórkach białaczkowych zwiększona aktywność kinazy tyrozynowej receptora FLT3 może wynikać $z$ nadekspresji $F L T 3$, autokrynnej i parakrynnej aktywacji receptora FLT3, mutacji aktywujących. Wykazano, że gen $F L T 3$ jest najczęściej zmutowanym genem zarówno u dorosłych, jak i u dzieci chorych na AML [1-3]. Nadekspresję FLT3 stwierdza się u około $50 \%$ chorych na ostre białaczki, rzadziej autokrynną i parakrynną aktywację receptora FLT3. Mutacje aktywujące genu FLT3, w tym wewnętrzną tandemową duplikację (FLT3-ITD, internal tandem duplication) części przybłonowej oraz mutacje punktowe $\mathrm{w}$ domenie kinazy tyrozynowej FLT3 (FLT3-TKD, tyrosine kinase domaine), wykrywa się u 20-37\% chorych na AML [4-8]. Mutacje FLT3-ITD stwierdzane są u około $30 \%$ chorych na AML, najczęściej wspólistnieją $z$ prawidłowym kariotypem. Wewnątrztandemowe duplikacje $F L T 3$ polegają na zdwojeniu od 3 do 400 par zasad i ich insercji w kierunku głowa-do-ogona w obrębie egzonu 14. lub 15. genu FLT3. Charakteryzują się dużym zróżnicowaniem lokalizacji insercji (IS, insertion sites) oraz ilości i wielkości zduplikowanych fragmentów. Natomiast mutacje punktowe FLT3-TKD wykrywa się u około $7 \%$ chorych [4]. Mutacje FLT3 aktywują wiele wewnątrzkomórkowych szlaków przekazywania sygnałów, w tym STAT5, MAPK, RAS, PI3AKT, prowadząc do zaburzenia cyklu komórkowego, niekontrolowanej proliferacji i zahamowania apoptozy komórek krwiotwórczych [9]. Opisywanymi $\mathrm{w}$ literaturze czynnikami istotnie pogarszającymi rokowanie chorych na AML są określone lokalizacje IS oraz wysoka ilościowa zawartość zmutowanego allelu (AR, allelic ratio) FLT3-ITD, czyli FLT3$-I T D^{\text {high }}$. Lokalizacja IS poza wewnątrzbłonową domeną, szczególnie w regionie B1-sheet TKD1, niekorzystnie wpływa na prawdopodobieństwo uzyskania całkowitej remisji (CR, complete remission) [10] w regionie B2-sheet TKD1 (FLT3_ITD627E) skutkuje pierwotną opornością na inhibitory FLT3 [11]. $Z$ wyjątkowo niekorzystnym rokowaniem wiąże się obecność FLT3-ITD ${ }^{\text {high }}$ definiowanego jako stosunek zmutowanego allela FLT3 do „dzikiego” (mutant to wild-type) wynoszący powyżej 0,51 [12]. U chorych na AML FLT3-ITD ${ }^{\text {high }}$ raportowano istotnie wyższą liczbę krwinek białych i blastozę w szpiku w porównaniu z chorymi na AML FLT3$-I T D^{\text {low }}[13]$.

Klinicznie mutacje aktywujące FLT3 korelują $z$ wysokim odsetkiem nawrotów AML, co przekłada się na krótsze przeżycie całkowite (OS, overall survival) chorych [8, 14-16]. W przypadku nawrotowej AML z obecnością mutacji FLT3 obserwuje się niskie odsetki odpowiedzi na terapie ratunkowe $[17,18]$. 
W pracy przedstawiono przypadek 20-letniego chorego na AML $z$ obecnością wysokiego stosunku allelicznego mutacji FLT3-ITD i lokalizacjami pozaszpikowymi AML przy rozpoznaniu. Dzięki dostępności midostauryny w programie wczesnego dostępu (MAP, Managed Access Program) firmy Novartis leczenie chorego zindywidualizowano chemioterapię indukującą według schematu DA „3 + 7" (daunorubicyna, arabinozyd cytozyny) skojarzono $z$ midostauryną. Po podaniu pierwszej linii leczenia $z$ midostauryną nie osiągnięto $C R$, zastosowano drugą chemioterapię indukującą według schematu CLAG-M (CLAG-M, kladrybina, arabinozyd cytozyny, czynnik stymulujący tworzenie kolonii granulocytów [G-CSF, granulocyte colony-stimulating factor], mitoksantron), po której osiągnięto CR $\mathrm{z}$ obecnością choroby resztkowej (MRD, minimal residual disease). Następnie podano jeden cykl chemioterapii konsolidującej $z$ wykorzystaniem wysokich dawek arabinozydu cytozyny. $Z$ uwagi na czynniki niekorzystnego rokowania: obecność wysokiego stosunku allelicznego mutacji FLT3-ITD, brak CR po pierwszym leczeniu indukującym remisję $\mathrm{w}$ skojarzeniu $\mathrm{z}$ inhibitorem FLT3, chorego zakwalifikowano do allogenicznego przeszczepienia krwiotwórczych komórek macierzystych (allo-HSCT, allogeneic hematopoietic stem cell transplantation). Po zastosowaniu kondycjonowania mieloablacyjnego (MAC, myeloablative conditioning) przeprowadzono allo-HSCT od dawcy niespokrewnionego (MUD, matched unrelated donor). Całkowita remisja utrzymuje się u chorego od 18 miesięcy.

\section{Opis przypadku}

Dwudziestoletni mężczyzna został przeniesiony do Kliniki Hematologii Instytutu Hematologii i Transfuzjologii (IHiT) w styczniu 2019 roku ze szpitala rejonowego $z$ powodu podejrzenia ostrego rozrostu układu krwiotwórczego. W wywiadzie chory zgłaszał znaczne obniżenie tolerancji wysiłku fizycznego oraz zaburzenia widzenia. Nie ujawniono istotnych chorób wspólistniejących $\mathrm{w}$ wywiadzie. $\mathrm{W}$ trakcie hospitalizacji w szpitalu rejonowym w badaniu okulistycznym stwierdzono rozległe wybroczyny w okolicy tarcz nerwu wzrokowego, wylewy przedsiatkówkowe, plamki Rotha oraz ogniska waty w obrębie obojga oczu. Przy przyjęciu do Kliniki Hematologii IHiT w badaniu przedmiotowym chorego stwierdzono uogólnioną limfadenopatię obwodową, hepatomegalię $(2 \mathrm{~cm}$ poniżej prawego łuku żebrowego), splenomegalię (4 cm poniżej lewego łuku żebrowego). W mor- fologii krwi obwodowej wykazano podwyższoną leukocytozę - liczba krwinek białych (WBC, white blood cell count) 70,08 G/1, niedokrwistość normocytową ze stężeniem hemoglobiny $(\mathrm{Hb})$ 6,6 g/dl, średnią objętość krwinek czerwonych (MCV, mean corpuscular volume) małopłytkowość $z$ liczbą płytek (PLT, platelets) wynoszącą $59 \mathrm{G} / 1$. W rozmazie krwi obwodowej stwierdzono przerwę białaczkową: $91 \%$ blastów, $6 \%$ promielocytów, $2 \%$ mielocytów, $21 \%$ limfocytów, anizocytozę krwinek czerwonych. $\mathrm{W}$ badaniach dodatkowych wykazano podwyższoną aktywność dehydrogenazy mleczanowej (LDH, lactate dehydrogenase), wynoszącą $1371 \mathrm{U} / \mathrm{l}$. W badaniu cytologicznym szpiku kostnego opisano rozmazy szpiku bogatokomórkowe $z$ obecnością $97,2 \%$ blastów. $\mathrm{W}$ badaniu metodą cytometrii przepływowej szpiku kostnego stwierdzono 96\% mieloblastów wskazujących na AML. W badaniach molekularnych szpiku kostnego przeprowadzonych $z$ zastosowaniem sekwencjonowania bezpośredniego oraz analizy długości fragmentów DNA (GeneScan) wykryto obecność zmutowanego allela FLT3-ITD, stosunek ilościowy (allelic ratio) frakcji zmutowanego allela FLT3-ITD względem „dzikiego” allela FLT3 wynosił 0,95 oraz nie wykazano obecności wariantów patogennych w eksonie 12 genu NPM1. W badaniu cytogenetycznym szpiku kostnego metodą prążkową stwierdzono prawidłowy kariotyp męski. W badaniu tomografii komputerowej wykazano limfadenopatię szyjną (do $27 \mathrm{~mm}$ ), śródpiersia (do $12 \mathrm{~mm}$ ), brzuszną (do $10 \mathrm{~mm}$ ), hepatomegalię (wymiar podłużny prawego płata około $20 \mathrm{~cm}$ ), splenomegalię $(51 \times 151 \times 182 \mathrm{~mm})$, naciek ściany ileum terminale grubości do $13 \mathrm{~mm}$ na długości $39 \mathrm{~mm}$. Na podstawie wykonanych badań rozpoznano ostrą białaczkę szpikową niesklasyfikowaną według klasyfikacji Światowej Organizacji Zdrowia 2016 (WHO, World Health Organization) z 2016 ro$\mathrm{ku}, \mathrm{z}$ grupy niekorzystnego ryzyka cytogenetyczno-molekularnego według klasyfikacji Europejskiej Sieci Białaczek (ELN, European LeukemiaNet) z 2017 roku.

Chorego zakwalifikowano do chemioterapii indukującej remisję $\mathrm{w}$ skojarzeniu $\mathrm{z}$ inhibitorem FLT3. Chemioterapię indukującą według schematu DA (daunorubicyna, arabinozyd cytozyny) „3 +7 ” w skojarzeniu $z$ następowym leczeniem midostauryną $\mathrm{w}$ dniach 8.-21. podano bez powikłań. Midostauryna była dobrze tolerowana, nie obserwowano istotnych działań niepożądanych. Po zastosowanej chemioterapii indukującej nie uzyskano CR. Następnie podano 2. indukcję według schematu CLAG-M (kladrybina, arabinozyd cytozyny, G-CSF, mitoksantron), po której osiagnnięto CR 
Z obecnością MRD. Ze względu na obecność czynników ryzyka zajęcia ośrodkowego układu nerwowego (OUN) przy rozpoznaniu: mutacji FLT3-ITD, lokalizacji pozaszpikowych AML, braku remisji po 1. indukcji, w okresie remisji wykonano nakłucie lędźwiowe i wykluczono zajęcie płynu mózgowo-rdzeniowego przez AML. Następnie pacjentowi podano 1 cykl chemioterapii konsolidującej remisję Z wykorzystaniem wysokich dawek arabinozydu cytozyny. W czerwcu 2019 roku przeprowadzono MUD allo-HSCT od dawcy niespokrewnionego w pełni zgodnego w zakresie ludzkich antygenów leukocytarnych (HLA, human leucocyte antigens) po kondycjonowaniu mieloablacyjnym według schematu fludarabina $z$ busulfanem i globuliną antytymocytarną (ATG, anti-thymocyte globulin). Pacjent pozostaje w $\mathrm{CR} \mathrm{z}$ ujemną MRD od 18 miesięcy.

\section{Dyskusja}

Rozwój terapii celowanych u chorych na AML umożliwia indywidualizację leczenia. Zastosowanie nowych inhibitorów kinaz tyrozynowych zarejestrowanych przez FDA i EMA do leczenia chorych na AML $z$ mutacjami FLT3 jest obiecującą perspektywą dla poprawy wyników leczenia i wydłużenia przeżycia chorych. Jednakże problemem pozostaje leczenie chorych $z$ obecnością FLT3-ITD ${ }^{\text {high }}$ wiążącego się $z$ utratą heterozygotyczności i wyjątkowo niekorzystnym rokowaniem.

W pracy Thiede i wsp. z 2002 roku wykazano wartość AR FLT3 powyżej 0,78 korelującą $\mathrm{z}$ istotnie statystycznie krótszymi OS i krótszymi przeżyciami wolnymi od choroby (DFS, disease-free survivals). Przeżycia chorych $z$ wartością AR poniżej 0,78 nie różniły się istotnie od przeżyć chorych bez mutacji FLT3 [7]. W związku $z$ tym kontrowersyjne pozostawało znaczenie prognostyczne niskich i pośrednich wartości AR FLT3-ITD, co potwierdzono te $\dot{z} \mathrm{w}$ innych pracach [19-22].

Niezależne grupy badawcze raportowały punkt odcięcia dla AR wynoszący 0,51 jako lepszy wskaźnik określający rokowanie [12, 21, 22]. Rokowanie niekorzystne odnotowano u chorych na AML $z$ wartościami AR powyżej 0,51. Na podstawie powyższych doniesień w klasyfikacji ELN 2017 ryzyko genetyczno-molekularne chorych na AML FLT3 stratyfikowane jest dla punktu odcięcia wartości AR wynoszącej 0,5 i statusu mutacji NPM1.

W literaturze brakuje porównania wyników leczenia oraz przeżyć chorych na AML FLT3high w zależności od zastosowania różnych inhibitorów FLT3 w pierwszej linii leczenia. Brak jest także jednoznacznych danych odnośnie do wrażliwości poszczególnych inhibitorów FLT3 na komórki białaczkowe w zależności od FLT3-ITD-AR [23-25].

Pośrednim dowodem skuteczności midostauryny niezależnie od FLT3-ITD-AR są dane raportowane przez Döhner i wsp. [13]. W pracy nie wykazano istotnych różnic w odpowiedziach na intensywną chemioterapię skojarzoną $\mathrm{z}$ midostauryną w grupach korzystnego (FLT3-ITD $\left.{ }^{\text {low }}, N P M 1^{\text {mut }}\right)$, pośredniego (FLT3-ITD ${ }^{\text {high }}, N P M 1^{\text {mut }}$ lub FLT3$\left.-I T D^{\text {low }}, N P M 1^{\mathrm{wt}}\right)$ i niekorzystnego $\left(F L T 3-I T D^{\text {high }}\right.$, $\left.N P M 1^{\text {wt }}\right)$ ryzyka według klasyfikacji ELN 2017. Największą korzyść w odniesieniu do przedłużonego przeżycia po dodaniu midostauryny do intensywnego leczenia oraz po allo-HSCT wykazano w grupie niekorzystnego ryzyka według ELN 2017 [13].

Przeszczepienie allogenicznych krwiotwórczych komórek macierzystych przeprowadzone w pierwszej CR (CR1) od w pełni zgodnych dawców rodzinnych (MRD, matched related donors) skutkowało wydłużeniem OS u chorych na AML FLT3$-I T D^{\text {high }} \mathrm{w}$ porównaniu $\mathrm{z}$ kontynuacją chemioterapii czy $z$ autologicznym przeszczepieniem krwiotwórczych komórek macierzystych (auto-HSCT, autologous hematopoietic stem cell transplantation) [26-33]. Jednakże w większości cytowanych prac porównań dokonano $z$ grupami historycznymi lub w analizach zgodnych $z$ faktycznie zastosowanym leczeniem [22, 28-30, 32, 33]. W kilku pracach potwierdzono wpływ wzrastającej wartości AR FLT3-ITD na wzrost skumulowanej częstości nawrotów (CIR, cumulative incidence of relapse) AML $[12,21,22]$. Efekt wpływu FLT3-ITD ${ }^{\text {high }}$ na wzrost CIR zanikał u chorych poddanych allo-HSCT w CR1, u których obserwowano równiez istotne wydłużenie OS i przeżycia wolnego od nawrotu (RFS, relapse-free survival) [12]. Natomiast w przypadku IS zlokalizowanych w obrębie TKD1 obserwowano niekorzystne rokowanie niepoddające się modyfikacji za pomocą różnych strategii leczenia poremisyjnego, w tym allo-HSCT [12]. Dlatego też u tych chorych allo-HSCT w CR1 może być rozważane jako opcja terapeutyczna skutkująca zmniejszeniem CIR w porównaniu z kontynuacją chemioterapii czy auto-HSCT, ale bez wpływu na istotne wydłużenie OS [12].

W pracy Schlenk i wsp. [12] nie wykazano istotnego wydłużenia OS i RFS u chorych na AML FLT3-ITD ${ }^{\text {low }}$ po zastosowaniu allo-HSCT w CR1 w porównaniu $\mathrm{z}$ kontynuacją chemioterapii czy te $\dot{z}$ auto-HSCT. Dlatego u tych chorych allo-HSCT pozostaje opcją leczenia poremisyjnego, szczególnie jeśli jest dostępny w pełni zgodny dawca, uwzględniając jednak ryzyko zgonu związanego $\mathrm{z}$ leczeniem (TRM, treatment-related mortality) 
i możliwość zastosowania innych strategii leczniczych w leczeniu poremisyjnym w CR1 [12, 34].

Odmienne wyniki do powyżej opisywanych obserwacji przedstawiłi Taylor i wsp., nie wykazując wpływu wartości AR FLT3-ITD na OS u chorych na AML poddanych allo-HSCT. Jednakże analizie poddano względnie małą liczbę - 152 chorych oraz stosowano niewystandaryzowane metody oceny AR FLT3-ITD [34].

Obecność mutacji FLT3-ITD w AML, pomimo poprawy wyników za pomocą przeprowadzenia allo-HSCT w CR1, nadal pozostaje czynnikiem niekorzystnego ryzyka i skutkuje wysokim odsetkiem nawrotów po allo-HSCT [32]. Toczą się badania, których przedmiotem jest ocena wpływu leczenia podtrzymującego inhibitorami FLT3 po allo-HSCT na zmniejszenie odsetka nawrotów i wydłużenie przeżycia. W pracy Schlenk i wsp. wykazano wydłużenie przeżycia wolnego od zdarzeń (EFS, event-free survival) i OS u chorych, u których rozpoczęto leczenie podtrzymujące midostauryną w ciągu 100 dni po allo-HSCT [35]. Trwają badania służące ocenie zastosowania gilterytynibu w leczeniu podtrzymującym po chemioterapii i po przeszczepieniu allogenicznych komórek krwiotwórczych (ClinicalTrials.gov). Istotne jest nie tylko zmniejszenie częstosci nawrotów AML, ale również zwiększenie odsetka remisji po indukcji, szczególnie w populacji chorych na AML FLT3-ITD ${ }^{\text {high }}$.

W prezentowanym przypadku potwierdzono niekorzystny wpływ obecności mutacji FLT3$-I T D^{\text {high }}$, oporność na chemioterapię indukującej pierwszej linii DA „3 +7 " skojarzoną z midostauryną. Całkowitą remisję $z$ obecnością MRD uzyskano po zastosowaniu drugiej indukcji według schematu CLAG-M. Dzięki szybkiemu przeprowadzeniu MUD allo-HSCT po kondycjonowaniu mieloablacyjnym $z$ wykorzystaniem fludrabiny, busulfanu i ATG całkowita remisja bez minimalnej choroby resztkowej utrzymuje się u chorego od 18 miesięcy.

\section{Piśmiennictwo}

1. Ley TJ, Miller C, Ding Li, et al. Cancer Genome Atlas Research Network. Genomic and epigenomic landscapes of adult de novo acute myeloid leukemia. N Engl J Med. 2013; 368(22): 2059-2074, doi: 10.1056/NEJMoa1301689, indexed in Pubmed: 23634996.

2. Papaemmanuil E, Döhner H, Campbell PJ, et al. Genomic Classification and Prognosis in Acute Myeloid Leukemia. N Engl J Med. 2016; 374(23): 2209-2221, doi: 10.1056/NEJMoa1516192, indexed in Pubmed: 27276561.

3. Bolouri H, Farrar JE, Triche T, et al. The molecular landscape of pediatric acute myeloid leukemia reveals recurrent structural alterations and age-specific mutational interactions. Nat Med. 2018; 24(1): 103-112, doi: 10.1038/nm.4439, indexed in Pubmed: 29227476 .
4. Patel JP, Gönen M, Figueroa ME, et al. Prognostic relevance of integrated genetic profiling in acute myeloid leukemia. N Engl J Med. 2012; 366(12): 1079-1089, doi: 10.1056/NEJMoa1112304, indexed in Pubmed: 22417203.

5. Christen F, Hoyer K, Yoshida K, et al. Genomic landscape and clonal evolution of acute myeloid leukemia with $\mathrm{t}(8 ; 21)$ : an international study on 331 patients. Blood. 2019; 133(10): 1140-1151, doi: 10.1182/blood-2018-05-852822, indexed in Pubmed: 30610028.

6. Iwai T, Yokota S, Nakao M, et al. Internal tandem duplication of the flt3 gene found in acute myeloid leukemia. Leukemia. 1996; 10(12): 1911-1918, indexed in Pubmed: 8946930.

7. Thiede C, Steudel C, Mohr B, et al. Analysis of FLT3-activating mutations in 979 patients with acute myelogenous leukemia: association with FAB subtypes and identification of subgroups with poor prognosis. Blood. 2002; 99(12): 4326-4335, doi: 10.1182/ /blood.v99.12.4326, indexed in Pubmed: 12036858.

8. Kiyoi H, Naoe T, Nakano Y, et al. Prognostic implication of FLT3 and N-RAS gene mutations in acute myeloid leukemia. Blood. 1999; 93(9): 3074-3080, indexed in Pubmed: 10216104.

9. Hannum C, Culpepper J, Campbell D, et al. Ligand for FLT3/ /FLK2 receptor tyrosine kinase regulates growth of haematopoietic stem cells and is encoded by variant RNAs. Nature. 1994; 368(6472): 643-648, doi: 10.1038/368643a0, indexed in Pubmed: 8145851.

10. Kayser S, Schlenk RF, Londono MC, et al. German-Austrian AML Study Group (AMLSG). Insertion of FLT3 internal tandem duplication in the tyrosine kinase domain-1 is associated with resistance to chemotherapy and inferior outcome. Blood. 2009; 114(12): 2386-2392, doi: 10.1182/blood-2009-03-209999, indexed in Pubmed: 19602710.

11. Breitenbuecher F, Markova B, Kasper S, et al. A novel molecular mechanism of primary resistance to FLT3-kinase inhibitors in AML. Blood. 2009; 113(17): 4063-4073, doi: 10.1182/ /blood-2007-11-126664, indexed in Pubmed: 19144992.

12. Schlenk RF, Kayser S, Bullinger L, et al. German-Austrian AML Study Group. Differential impact of allelic ratio and insertion site in FLT3-ITD-positive AML with respect to allogeneic transplantation. Blood. 2014; 124(23): 3441-3449, doi: 10.1182/ /blood-2014-05-578070, indexed in Pubmed: 25270908.

13. Döhner K, Thiede C, Jahn N, et al. Impact of NPM1/FLT3-ITD genotypes defined by the 2017 European LeukemiaNet in patients with acute myeloid leukemia. Blood. 2020; 135(5): 371-380, doi: 10.1182/blood.2019002697, indexed in Pubmed: 31826241.

14. Rombouts WJ, Blokland I, Löwenberg B, et al. Biological characteristics and prognosis of adult acute myeloid leukemia with internal tandem duplications in the Flt3 gene. Leukemia. 2000; 14(4): 675-683, doi: 10.1038/sj.leu.2401731, indexed in Pubmed: 10764154.

15. Abu-Duhier FM, Goodeve AC, Wilson GA, et al. FLT3 internal tandem duplication mutations in adult acute myeloid leukaemia define a high-risk group. Br J Haematol. 2000; 111(1): 190-195, doi: 10.1046/j.1365-2141.2000.02317.x, indexed in Pubmed: 11091200.

16. Kottaridis PD, Gale RE, Frew ME, et al. The presence of a FLT3 internal tandem duplication in patients with acute myeloid leukemia (AML) adds important prognostic information to cytogenetic risk group and response to the first cycle of chemotherapy: analysis of 854 patients from the United Kingdom Medical Research Council AML 10 and 12 trials. Blood. 2001; 98(6): 1752-1759, doi: 10.1182/blood.v98.6.1752, indexed in Pubmed: 11535508.

17. Wagner K, Damm F, Thol F, et al. FLT3-internal tandem duplication and age are the major prognostic factors in patients with relapsed acute myeloid leukemia with normal karyotype. Haemato- 
logica. 2011; 96(5): 681-686, doi: 10.3324/haematol.2010.034074, indexed in Pubmed: 21242187.

18. Levis M, Ravandi F, Wang ES, et al. Results from a randomized trial of salvage chemotherapy followed by lestaurtinib for patients with FLT3 mutant AML in first relapse. Blood. 2011; 117(12): 3294-3301, doi: 10.1182/blood-2010-08-301796, indexed in Pubmed: 21270442.

19. Schnittger S, Bacher U, Haferlach C, et al. Diversity of the juxtamembrane and TKD1 mutations (exons 13-15) in the FLT3 gene with regards to mutant load, sequence, length, localization, and correlation with biological data. Genes Chromosomes Cancer. 2012; 51(10): 910-924, doi: 10.1002/gcc.21975, indexed in Pubmed: 22674490.

20. Whitman SP, Archer KJ, Feng L, et al. Absence of the wild-type allele predicts poor prognosis in adult de novo acute myeloid leukemia with normal cytogenetics and the internal tandem duplication of FLT3: a cancer and leukemia group B study. Cancer Res. 2001; 61(19): 7233-7239, indexed in Pubmed: 11585760.

21. Gale RE, Green C, Allen C, et al. Medical Research Council Adult Leukaemia Working Party. The impact of FLT3 internal tandem duplication mutant level, number, size, and interaction with NPM1 mutations in a large cohort of young adult patients with acute myeloid leukemia. Blood. 2008; 111(5): 2776-2784, doi: 10.1182/blood-2007-08-109090, indexed in Pubmed: 17957027.

22. Pratcorona M, Brunet S, Nomdedéu J, et al. Grupo Cooperativo Para el Estudio y Tratamiento de las Leucemias Agudas Mieloblásticas. Favorable outcome of patients with acute myeloid leukemia harboring a low-allelic burden FLT3-ITD mutation and concomitant NPM1 mutation: relevance to post-remission therapy. Blood. 2013; 121(14): 2734-2738, doi: 10.1182/ /blood-2012-06-431122, indexed in Pubmed: 23377436.

23. Brown P, Meshinchi S, Levis M, et al. Pediatric AML primary samples with FLT3/ITD mutations are preferentially killed by FLT3 inhibition. Blood. 2004; 104(6): 1841-1849, doi: 10.1182/ /blood-2004-03-1034, indexed in Pubmed: 15166029.

24. Pratz KW, Sato T, Murphy KM, et al. FLT3-mutant allelic burden and clinical status are predictive of response to FLT3 inhibitors in AML. Blood. 2010; 115(7): 1425-1432, doi: 10.1182/ /blood-2009-09-242859, indexed in Pubmed: 20007803.

25. Cucchi DGJ, Denys B, Kaspers GJL, et al. RNA-based -ITD allelic ratio is associated with outcome and ex vivo response to FLT3 inhibitors in pediatric AML. Blood. 2018; 131(22): 2485-2489, doi: 10.1182/blood-2017-12-819508, indexed in Pubmed: 29669779.

26. Paschka P, Schlenk RF, Gaidzik VI, et al. German-Austrian AML Study Group, German-Austrian Acute Myeloid Leukemia Study Group. Mutations and treatment outcome in cytogenetically normal acute myeloid leukemia. N Engl J Med. 2008; 358(18): 1909-1918, doi: 10.1056/NEJMoa074306, indexed in Pubmed: 18450602.
27. Gale RE, Hills R, Kottaridis PD, et al. No evidence that FLT3 status should be considered as an indicator for transplantation in acute myeloid leukemia (AML): an analysis of 1135 patients, excluding acute promyelocytic leukemia, from the UK MRC AML10 and 12 trials. Blood. 2005; 106(10): 3658-3665, doi: 10.1182/blood-2005-03-1323, indexed in Pubmed: 16076872.

28. Bornhäuser M, Illmer T, Schaich M, et al. AML SHG 96 study group. Improved outcome after stem-cell transplantation in FLT3/ /ITD-positive AML. Blood. 2007; 109(5): 2264-5; author reply 2265, doi: 10.1182/blood-2006-09-047225, indexed in Pubmed: 17312001.

29. Labouré G, Dulucq S, Labopin M, et al. Potent graft-versus-leukemia effect after reduced-intensity allogeneic SCT for intermediate-risk AML with FLT3-ITD or wild-type NPM1 and CEBPA without FLT3-ITD. Biol Blood Marrow Transplant. 2012; 18(12): 1845-1850, doi: 10.1016/j.bbmt.2012.06.012, indexed in Pubmed: 22766221.

30. Doubek M, Muzík J, Szotkowski T, et al. Is FLT3 internal tandem duplication significant indicator for allogeneic transplantation in acute myeloid leukemia? An analysis of patients from the Czech Acute Leukemia Clinical Register (ALERT). Neoplasma. 2007; 54(1): 89-94, indexed in Pubmed: 17233551.

31. Sengsayadeth SM, Jagasia M, Engelhardt BG, et al. Allo-SCT for high-risk AML-CR1 in the molecular era: impact of FLT3/ITD outweighs the conventional markers. Bone Marrow Transplant. 2012; 47(12): 1535-1537, doi: 10.1038/bmt.2012.88, indexed in Pubmed: 22659680.

32. Brunet S, Labopin M, Esteve J, et al. Impact of FLT3 internal tandem duplication on the outcome of related and unrelated hematopoietic transplantation for adult acute myeloid leukemia in first remission: a retrospective analysis. J Clin Oncol. 2012; 30(7): 735-741, doi: 10.1200/JCO.2011.36.9868, indexed in Pubmed: 22291086.

33. DeZern AE, Sung A, Kim S, et al. Role of allogeneic transplantation for FLT3/ITD acute myeloid leukemia: outcomes from 133 consecutive newly diagnosed patients from a single institution. Biol Blood Marrow Transplant. 2011; 17(9): 1404-1409, doi: 10.1016/j.bbmt.2011.02.003, indexed in Pubmed: 21324374.

34. Taylor E, Morris K, Ellis M, et al. FLT3-ITD positive acute myeloid leukemia: A retrospective analysis of the role of allogeneic transplant and allelic ratio in patient management. Asia Pac J Clin Oncol. 2018; 14(6): 426-430, doi: 10.1111/ajco.12827, indexed in Pubmed: 29383835.

35. Schlenk RF, Weber D, Fiedler W, et al. German-Austrian AML Study Group. Midostaurin added to chemotherapy and continued single-agent maintenance therapy in acute myeloid leukemia with FLT3-ITD. Blood. 2019; 133(8): 840-851, doi: 10.1182/ /blood-2018-08-869453, indexed in Pubmed: 30563875. 